\title{
Blockchain Technology - Current Status and Future Research Opportunities in Various Areas of Healthcare Industry
}

\author{
P. S. Aithal ${ }^{1}$, Architha Aithal ${ }^{2}, \&$ Edwin Dias ${ }^{3,4}$ \\ ${ }^{1}$ College of Management \& Commerce, Srinivas University, Mangalore - 575 001, India \\ OrcidID: 0000-0002-4691-8736; E-mail: psaithal@gmail.com \\ ${ }^{2}$ Intern of Pharm D., Srinivas College of Pharmacy, Valachil, Mangalore, Karnataka State, India \\ ORCID: https://orcid.org/0000-0003-2361-5166; E-mail: aithalarchitha@gmail.com \\ ${ }^{3}$ Professor \& Head, Department of Paediatrics, Srinivas Institute of Medical Sciences and \\ Research Centre, Mangalore, Karnataka State, India \\ ${ }^{4}$ Adjunct Research Professor, College of Allied Health Sciences, Srinivas University, Mangalore, \\ India \\ ORCID: 0000-0001-6266-795X; Email: dredwindias@gmail.com
}

Area/Section: Health Science.

Type of the Paper: Review based Analysis.

Type of Review: Peer Reviewed as per $|\mathrm{C}| \mathrm{O}|\mathrm{P}| \mathrm{E} \mid$ guidance.

Indexed in: OpenAIRE.

DOI: https://doi.org/10.5281/zenodo.5105896

Google Scholar Citation: IJHSP

\section{How to Cite this Paper:}

Aithal, P. S., Architha Aithal, \& Edwin Dias, (2021). Blockchain Technology - Current Status and Future Research Opportunities in Various Areas of Healthcare Industry. International Journal of Health Sciences and Pharmacy (IJHSP), 5(1), 130-150. DOI: https://doi.org/10.5281/zenodo.5105896

International Journal of Health Sciences and Pharmacy (IJHSP)

A Refereed International Journal of Srinivas University, India.

Crossref DOI : https://doi.org/10.47992/IJHSP.2581.6411.0070

(C) With Author.

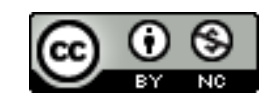

This work is licensed under a Creative Commons Attribution-Non-Commercial 4.0 International License subject to proper citation to the publication source of the work.

Disclaimer: The scholarly papers as reviewed and published by the Srinivas Publications (S.P.), India are the views and opinions of their respective authors and are not the views or opinions of the SP. The SP disclaims of any harm or loss caused due to the published content to any party. 


\title{
Blockchain Technology - Current Status and Future Research Opportunities in Various Areas of Healthcare Industry
}

\author{
P. S. Aithal ${ }^{1}$, Architha Aithal ${ }^{2}, \&$ Edwin Dias ${ }^{3,4}$ \\ ${ }^{1}$ College of Management \& Commerce, Srinivas University, Mangalore - 575 001, India \\ ORCID: 0000-0002-4691-8736; E-mail: psaithal@gmail.com \\ ${ }^{2}$ Intern of Pharm D., Srinivas College of Pharmacy, Valachil, Mangalore, Karnataka State, India \\ ORCID: https://orcid.org/0000-0003-2361-5166; E-mail: aithalarchitha@gmail.com \\ ${ }^{3}$ Professor \& Head, Department of Paediatrics, Srinivas Institute of Medical Sciences and \\ Research Centre, Mangalore, Karnataka State, India \\ ${ }^{4}$ Adjunct Research Professor, College of Allied Health Sciences, Srinivas University, Mangalore, \\ India \\ ORCID: 0000-0001-6266-795X; Email: dredwindias@ gmail.com
}

\begin{abstract}
Purpose: Blockchain technology is one of the emerging Information Communication and Computation (ICCT) underlying technologies of the 21 st century with potential applications in primary, secondary, tertiary, and quaternary industry sectors. In this paper, we have identified and analyzed some of the potential fields of the healthcare industry that can get benefit by means of using blockchain technology principles. Based on a systematic review on the development of blockchain technology and its application in healthcare sector to improve the quality of healthcare services, this paper identifies some of the application areas in the healthcare industry including Healthcare Security \& Authentication aspects, Clinical Trials \& Precision Medicine, Personalizing the Healthcare Services, Healthcare Data Management, Strengthening Public Health Surveillance, eHealthcare to Customers, Healthcare Administration \& Medicine Management, Telehealth \& Telemedicine, Managing Medical Imaging, Developing Smart Healthcare System, and Healthcare Information System. The purpose also includes the analysis of the current implementation challenges of blockchain technology in healthcare industry services.

Methodology: The study is descriptive and exploratory in nature. The related information is collected from various secondary sources for review. The secondary sources include published literature from various scholarly journals searched through Google scholar by means of identified keywords.
\end{abstract}

Results/Findings: Based on a systematic review, we have identified the current status of the use of blockchain in several areas of healthcare sector, desired status called ideal status, and the research gap of use of blockchain technology in various application areas of the healthcare industry along with identification of various possible research agendas for future research.

Originality/Value: It is found that blockchain technology facilitates for the improvement of quality services in the healthcare sector and various research agendas are proposed to carry out further research for patient satisfaction and comfortability.

Type of the Paper: Review based research analysis.

Keywords: ICCT underlying technologies, Blockchain technology, Innovations in healthcare, Healthcare services, Distributed Ledger, Current implementations

\section{INTRODUCTION :}

The twelve underlying emerging technologies of Information Communication and Computation Technology (ICCT) including blockchain technology are considered as general-purpose technologies of the $21^{\text {st }}$ century [1]. A general-purpose technology or GPT is a technology that has potential applications in multiple industries with the new methods of producing, serving, and inventing opportunities with a protracted aggregate impact. Electricity and information technology (IT) probably are the two most important GPTs until the 20th century. A GPT can be a product, a process, technology or an organizational system. Whole eras of technical progress 
and growth appear to be driven by a few 'General Purpose Technologies' (GPT's), such as the steam engine, the electric motor, and semiconductors. GPT's are characterized by pervasiveness to many industry sectors, inherent potential for technical improvements, and innovation complementarities to many applications, giving rise to increasing scale of operation. Economist Richard Lipsey and Kenneth Carlaw [2] suggested that there have only been 24 technologies in history that have been identified as true GPTs. They define a transforming GPT follows four criteria which are listed below [3]: (1) GPT is a single, recognizable generic technology. (2) Initially, GPT has much scope for improvement but comes to be widely used across the economy. (3) GPT has many different uses in many areas to solve problems or to provide comfortability. (4) GPT creates many spill-over effects to spread its base to many sectors. General purpose technologies have the potential to reshape the economy of the world and boost productivity across all sectors and industries. Such transformations are far more than simple technical innovation, or a new discovery. However, such technologies often require a wholesale remaking of infrastructure environments, of business models, and of cultural norms. There are three fundamental features of GPTs that differentiate them from other technologies which are (1) Pervasiveness - The GPT should spread to most sectors. (2) Improvement - The GPT should get better over time and, hence, should keep lowering the costs of its users. (3) Innovation spawning - The GPT should support to invent and produce new products or processes. Blockchain technology possess each of these characteristics to some degree, and considered as a potential tool for innovations in multiple industry sectors including primary industry sector, secondary industry sector, tertiary industry sector, and quaternary industry sector [4] [5].

Blockchain is one of the undeniably clever innovations under general purpose universal technology called Information Communication and Computation Technology (ICCT) [6]. Blockchain has been implemented over a decade. Like any blockchain digital technology, recognition experiments were carried out in various industries before successful use. Each block stores the transaction information, each block is saved with a single code called "hash". A blockchain-based system is a publicly shared digital block system (i.e., a decentralized one) in which all participant blocks are distributed geographically and linked across different network types. Blockchain networks can be segregated and permitted into two key styles as permissioned \& permissionless Open-ended systems like Bitcoin and Ethereum are permissionless. They are open to the public. Any node will carry out transactions and also engage in a phase of consensus to advance the blockchain. Permissioned registered Networks, such as Hyperledger Fabric and Multichain, are aimed at consortia where limited options exist. Even though customers are permitted to request transactions, the blockchain's development is restricted to a defined community of peering nodes run by consortium members. Indian healthcare system has been one of the rapidly growing sectors with the goal of reaching more people every year.

It is a technology for record creation across many computers or digital devices of a process or an activity which cannot be altered retroactively, without altering its subsequent processes or activities. Blockchain technology allows a system to own digital goods, assets, and data and capable to trace the history of everything which is created as a footprint in the past transactions. Thus, an ideal blockchain technology is expected to have the capability to trace the history of everything which created a footprint in the past. In simple words, blockchain technology can be used in each financial transaction and is digitally signed to ensure its authenticity and not allowed to tamper it, so that a ledger created with the existing transactions within it are assumed to be of high integrity. It is expected that blockchain technology is expected to help total stoppage of financial frauds and hence contributing to eradicate corruptions in this world. Blockchain technology has applications in financial transactions, healthcare systems, education, supply chain systems, etc.

Block chain-based framework lets users to script transactions \& contracts to enable transactions that go beyond money. Here the required verification resource would be ledger depending on the script size specified by the user [7]. Chaum's work on the decentralized essence of the payment system enables the blockchain to inaugurate a new age beyond global payments [8]. Blockchain can indeed be called a public ledger, as well as all agreed transactions is stored in a blocklist. The chains grow as it continually adds new links. Asymmetric encryption and distributed consensus algorithms were implemented for the user security and accuracy of a ledger. Usually, the blockchain has core characteristics of decentralization, longevity, accountability, and auditability. With these devices, Blockchain can significantly save on costs and increase efficiency [9]. Since it enables payment to be done without any bank or intermediary, blockchain can be used in various financial services, such as digital assets, transactions, and electronic payments [10], [11]. Blockchain is the decentralized transaction mechanism for Bitcoin, built to distribute and pass money for 
holders of the Bitcoin currency. This technique would support the public ledger for all ever-executed Bitcoin transactions, with no third-party entity control, the advantage of Blockchain is that after all nodes have approved the data, the public database cannot be modified or withdrawn. Blockchain is now well known for its data privacy and security features. Blockchain technology can also be applied to other applications. It has built an ecosystem within a cloud service for digital contracts and peer-to-peer data sharing [12]. BCT acts as a digital exchange for healthcare while allowing patents to retain excessive control over their information, exposure to medical data and promote the transition to patients. [13]. In some medical systems, smart contracts could be used, like payment $\&$ insurance, that allows automate the process and reduce costs.

Blockchain technology offers several direct and indirect benefits in healthcare industry which include [14]:

(1) Distributed and Secured Storage of patient's medical and clinical Data.

(2) Supports Patient Centric System.

(3) Transparency in the audit processes of clinical trials.

(4) Healthcare service quality management and tracking of facilities and services.

(5) Systematic, secured and transparent healthcare supply chain management.

(6) Trusted and Immutable Control and Management System.

(7) Facilitates patient mediated information exchange.

(8) Data is encrypted using immutable blocks which cannot be altered individually without disclosing to other stakeholders.

(9) Remove central node dependency (everyone shares equal rights and privileges).

(10) Better engagement of patients in every aspect from diagnosis to treatment and cure.

In this paper, based on a systematic review, we have identified current status, desired status called ideal status and the research gap of use of blockchain technology in various application areas of healthcare industry including Healthcare Security \& Authentication aspects, Clinical Trials \& Precision Medicine, Personalizing the Healthcare Services, Healthcare Data Management, Strengthening Public Health Surveillance, eHealthcare to Customers, Healthcare Administration \& Medicine Management, Telehealth \& Telemedicine, Managing Medical Imaging, Developing Smart Healthcare System, and Healthcare Information System along with identification of various possible research agendas for future research.

\section{OBJECTIVES :}

This study is limited to the discussion on possible innovations in healthcare sector services using blockchain technology. The main objectives are :

(1) To learn blockchain technology as distributed ledger tool and its potential capabilities across industries,

(2) To find out the current status and potential usage of blockchain technology in the healthcare industry sector based on a systematic review,

(3) To predict the possible innovations in the healthcare sector using blockchain technology,

(4) To identify the opportunities and challenges of blockchain technology in various areas of healthcare service and stages of its implementation,

(5) To develop and analyse various research agendas by identifying the research gap on the use of blockchain technology in the healthcare industry.

\section{METHODOLOGY :}

The study is descriptive and exploratory in nature. The related information is collected from various secondary sources for review. The secondary sources include published literature from various scholarly journals searched through Google scholar by means of identified keywords. The related research works published in these journal articles are summarized to know the current status of using blockchain technology.

\section{RELATED WORKS ON CURRENT USAGE IN VARIOUS RELARED AREAS :}

Blockchain has the potential to preserve an incorruptible, open, immutable database of all data that includes an individual's private and concealing identity with complex and protected codes that can protect the security of medical data. The collaborative design of the system also helps patients, physicians, and healthcare professionals to easily and safely share the same information [15]. The following section reviews some of the specific applications of blockchain technology in healthcare sector.

\subsection{Blockchain in Security \& Authentication Aspects:}

Blockchain can be used for securing the health documents of all stages for a long period and any kind of 
intrusion or modification without the consent of people or departments involved are not possible. In blockchain based ledger storage models used in the healthcare sectors, a decentralized network of nodes is usually created using cryptographic processes computed by all members involved in various sections based on consensus mechanisms, digital signatures, and hash chains and hence it has highly reliable storage capabilities and provides numerous service qualities including traceability, integrity, security, and nonrepudiation. These documents are usually stored in a public decentralized but in a privacy-preserving manner. A medical record can be both patient files and medical data related to the collection and usage of various resources during and after treatment in hospitals that are retrieved from various departments, patient body sensors and other automated applications. As medical records are now stored in digital formats, it requires additional security and role-based privileges to protect health information in the form of healthcare records security that includes access controls, authentication, nonreproduction of records by ensuring information and document integrity, confidentiality, and availability in the right time for authenticated users. Table 1 lists some of published research work on use of blockchain in security and authentication.

Table 1 : Published research work on Blockchain in Security \& Authentication

\begin{tabular}{|l|l|l|l|}
\hline $\begin{array}{l}\text { S. } \\
\text { No. }\end{array}$ & Area & Issues and Outcome & Reference \\
\hline 1 & $\begin{array}{l}\text { Blockchain based } \\
\text { security }\end{array}$ & $\begin{array}{l}\text { Securing and authenticating healthcare } \\
\text { records }\end{array}$ & $\begin{array}{l}\text { Pandey, P., et al. } \\
(2020) \text {. [16] }\end{array}$ \\
\hline 2 & $\begin{array}{l}\text { Blockchain based } \\
\text { security }\end{array}$ & $\begin{array}{l}\text { Healthcare security based on internet } \\
\text { of things }\end{array}$ & $\begin{array}{l}\text { Srivastava, G., et al. } \\
(2020) . \text { [17] }\end{array}$ \\
\hline 3 & $\begin{array}{l}\text { Survey on blockchain } \\
\text { based security }\end{array}$ & $\begin{array}{l}\text { Privacy threats and potential } \\
\text { applications }\end{array}$ & $\begin{array}{l}\text { Soni, S., et al. (2019). } \\
\text { [18] }\end{array}$ \\
\hline 4 & $\begin{array}{l}\text { Blockchain based } \\
\text { security }\end{array}$ & Security challenges using IoT & $\begin{array}{l}\text { Kumar, N. M., et al. } \\
\text { (2018). [19] }\end{array}$ \\
\hline 5 & $\begin{array}{l}\text { Blockchain based health } \\
\text { Applications }\end{array}$ & IoT based e-health solutions & $\begin{array}{l}\text { Neto, M. M., et al. } \\
\text { (2019). [20] }\end{array}$ \\
\hline 6 & $\begin{array}{l}\text { Blockchain based } \\
\text { framework }\end{array}$ & For securing electronic health records & $\begin{array}{l}\text { Vora, J., et al. (2018). } \\
\text { [21] }\end{array}$ \\
\hline
\end{tabular}

\subsection{Blockchain in Clinical Trials \& Precision Medicine:}

In healthcare industry, clinical trials are essential requirements to test the suitability of the medicine to a specific disease and the associated side effects. For clinical trials patient recruitment is known to be challenging aspect and failure to meet patient recruitment goals in time results in a waste of funds and time, incomprehensible statistical results, and unexpected delay in study period that could increase the planned recruitment timeline of patients. It is observed that $86 \%$ of clinical trials don't achieve their recruitment goals on time ${ }^{3}$ and $19 \%$ of registered clinical trials were either closed or terminated due to failure to reach expected enrolment [22].

Systematic and valid patient enrolment is essential in clinical trials to get conclusive results failure which may cause premature trail termination. Blockchain technology features a peer-to-peer system with external audited transaction capabilities, data security supports, and privacy for patients are suitable for an innovative model to be used in clinical trial recruitment of stakeholders. Blockchain model also supports essential features like data decentralization, immutability, ensuring data provenance, and public auditability. In blockchain based model, all the transactions are distributively stored into each node in any active electronic device without hardware requirements. All transactions need to be validated by the user in the blockchain before it is written into the system. Since the system is fully decentralized, all the transactions can be audited publicly by all the users and hence it constitutes a fool proof system.

A blockchain based system called "Smart Contract" is developed which is a programmable self-executing protocol that regulates the blockchain transactions. Smart Contract system is a coded protocol agreed between senders and receivers initially proposed by Nick Szabo in 1996 to regulate all transactions on the distributed ledger system [23]. Most blockchain systems proposed in clinical trials have added a smart contract function to their protocols such as Ethereum and Hyperledger [24]. Since the Ethereum blockchain comes with a builtin Turing complete programming language used for the smart contract, any computational problem such as patient matching for recruitment, or checking the validity of a clinical trial can be coded as a smart contract 
[25]. Thus, blockchain based smart contract system can handle current recruitment challenges, patient engagement, automated subject matching, patient recruitment, and trial-based contracts management. Table 2 lists some of published research work on use of blockchain in Clinical Trials \& Precision Medicine

Table 2 : Published research work on Blockchain in Clinical Trials \& Precision Medicine

\begin{tabular}{|l|l|l|l|}
\hline $\begin{array}{l}\text { S. } \\
\text { No. }\end{array}$ & Area & Issues and Outcome & Reference \\
\hline 1 & $\begin{array}{l}\text { Clinical trials using } \\
\text { Blockchain }\end{array}$ & $\begin{array}{l}\text { Prototype of running clinical trials in an } \\
\text { untrustworthy environment }\end{array}$ & $\begin{array}{l}\text { Wong, D. R., et } \\
\text { al. (2019). [26] }\end{array}$ \\
\hline 2 & $\begin{array}{l}\text { Clinical trials using } \\
\text { blockchain }\end{array}$ & $\begin{array}{l}\text { Improving data transparency smart } \\
\text { contracts }\end{array}$ & $\begin{array}{l}\text { Nugent, T., et al. } \\
\text { (2016). [27] }\end{array}$ \\
\hline 3 & $\begin{array}{l}\text { Using blockchain } \\
\text { technology to manage } \\
\text { clinical trials data }\end{array}$ & A proof-of-concept study & $\begin{array}{l}\text { Maslove, D. M., } \\
\text { et al. (2018). [28] }\end{array}$ \\
\hline 4 & $\begin{array}{l}\text { Blockchain protocols in } \\
\text { clinical trials }\end{array}$ & Transparency and traceability of consent & $\begin{array}{l}\text { Benchoufi, M., et } \\
\text { al (2017). [29] }\end{array}$ \\
\hline 5 & $\begin{array}{l}\text { Clinical trials using } \\
\text { Blockchain }\end{array}$ & For improving clinical research quality & $\begin{array}{l}\text { Benchoufi, M., et } \\
\text { al. (2017). [30] }\end{array}$ \\
\hline 6 & $\begin{array}{l}\text { Role of blockchain and } \\
\text { IoT in clinical trials }\end{array}$ & $\begin{array}{l}\text { Recruiting participants for digital clinical } \\
\text { trials }\end{array}$ & $\begin{array}{l}\text { Angeletti, F., et } \\
\text { al. (2017). [31] }\end{array}$ \\
\hline 7 & $\begin{array}{l}\text { Clinical trials using } \\
\text { Blockchain }\end{array}$ & To improve the outcomes of clinical trials & $\begin{array}{l}\text { Borioli, G. S., et } \\
\text { al. (2018). [32] }\end{array}$ \\
\hline 8 & $\begin{array}{l}\text { Blockchain for clinical } \\
\text { trials }\end{array}$ & $\begin{array}{l}\text { A framework for managing and monitoring } \\
\text { data in multi-site clinical trials }\end{array}$ & $\begin{array}{l}\text { Choudhury, O., } \\
\text { et al. (2019). [33] }\end{array}$ \\
\hline 9 & $\begin{array}{l}\text { Blockchain for clinical } \\
\text { trials }\end{array}$ & $\begin{array}{l}\text { Ensuring protocol compliance and data } \\
\text { transparency using Blockchain smart } \\
\text { contracts. }\end{array}$ & $\begin{array}{l}\text { Omar, I. A., et al. } \\
\text { (2020). [34] }\end{array}$ \\
\hline 10 & $\begin{array}{l}\text { Blockchain for clinical } \\
\text { trials and precision } \\
\text { medicine }\end{array}$ & $\begin{array}{l}\text { Design of a blockchain platform for clinical } \\
\text { trial and precision medicine }\end{array}$ & $\begin{array}{l}\text { Shae, Z., et al. } \\
\text { (2017). [35] }\end{array}$ \\
\hline 11 & $\begin{array}{l}\text { Blockchain for clinical } \\
\text { trials }\end{array}$ & $\begin{array}{l}\text { A Hybrid Blockchain Design for Patient } \\
\text { Recruitments and Persistent Monitoring for } \\
\text { Clinical Trials }\end{array}$ & $\begin{array}{l}\text { Zhuang, Y., et al. } \\
\text { (2018). [36] }\end{array}$ \\
\hline 12 & $\begin{array}{l}\text { Blockchain for clinical } \\
\text { trials }\end{array}$ & $\begin{array}{l}\text { Blockchain-enabled clinical study consent } \\
\text { management }\end{array}$ & $\begin{array}{l}\text { Jung, H. H., et al. } \\
\text { (2020). [37] }\end{array}$ \\
\hline
\end{tabular}

\subsection{Blockchain in Personalizing the Healthcare Services:}

The digital healthcare system has a biggest challenge of secured data sharing and interoperability between applications data sources and other external systems. Personal healthcare records created for digital healthcare system provides access to patients to some extent and allows them to control it by means of interoperability in order to deliver personalized care. But as per the government regulations, supports to protect personal and private data and there is a need of maintaining security and transparency in the areas of consent, anonymization and data ownership [38]. Blockchain technology-based platform allows patients to provide permission to use the data by means of use of token-based permission. Patients can also provide permission to use the data for healthcare professionals and researchers to access their health history and wellbeing and to get medical services from global market to improve their health without any illegal modifications. Table 3 lists some of published research work on use of blockchain in Personalizing the Healthcare Services.

Table 3 : Related scholarly work in Blockchain in Personalizing the Healthcare Services

\begin{tabular}{|l|l|l|l|}
\hline $\begin{array}{l}\text { S. } \\
\text { No. }\end{array}$ & Area & Issues and Outcome & Reference \\
\hline 1 & $\begin{array}{l}\text { Blockchain in } \\
\text { Personalizing the } \\
\text { Healthcare Services }\end{array}$ & $\begin{array}{l}\text { A Novel Smart Contract System for } \\
\text { eReferral in Healthcare: Healthchain }\end{array}$ & $\begin{array}{l}\text { Chenthara, S., et } \\
\text { al. (2020). [39] }\end{array}$ \\
\hline
\end{tabular}




\begin{tabular}{|l|l|l|l|}
\hline 2 & $\begin{array}{l}\text { Blockchain in } \\
\text { personalizing patient- } \\
\text { centric health }\end{array}$ & $\begin{array}{l}\text { A patient-centric health information } \\
\text { exchange framework using blockchain } \\
\text { technology }\end{array}$ & $\begin{array}{l}\text { Zhuang, Y., et al. } \\
\text { (2020). [40] }\end{array}$ \\
\hline 3 & $\begin{array}{l}\text { Blockchain-based } \\
\text { personal health record } \\
\text { exchange }\end{array}$ & $\begin{array}{l}\text { An architecture and management platform } \\
\text { for development and usability }\end{array}$ & $\begin{array}{l}\text { Lee, H. A., et al. } \\
\text { (2020). [41] }\end{array}$ \\
\hline 4 & $\begin{array}{l}\text { Blockchain for digital } \\
\text { health }\end{array}$ & Prospects and challenges & $\begin{array}{l}\text { Evangelatos, N., } \\
\text { et al. (2020). [42] }\end{array}$ \\
\hline 5 & $\begin{array}{l}\text { Blockchain in } \\
\text { Personalizing Health } \\
\text { Records }\end{array}$ & $\begin{array}{l}\text { Blockchain-Based Personal Health Records } \\
\text { for Patients' Empowerment. }\end{array}$ & $\begin{array}{l}\text { El Rifai, O., et al. } \\
\text { (2020). [43] }\end{array}$ \\
\hline 6 & $\begin{array}{l}\text { Blockchain, } \\
\text { Interoperability, and } \\
\text { Self-Sovereign Identity }\end{array}$ & Trust Me, It's My Data & $\begin{array}{l}\text { StClair, J., et al. } \\
\text { (2020). [44] }\end{array}$ \\
\hline 7 & $\begin{array}{l}\text { Blockchain for digital } \\
\text { health }\end{array}$ & $\begin{array}{l}\text { EDI with blockchain as an enabler for } \\
\text { extreme automation in healthcare }\end{array}$ & $\begin{array}{l}\text { Fiaidhi, J., et al. } \\
\text { (2020). [45] }\end{array}$ \\
\hline
\end{tabular}

\subsection{Blockchain in Healthcare Data Management:}

A blockchain is a particular type of database by its design and is a kind of read-only-once database. The blockchain databases are designed and created only once and not allowed to be edited or deleted by any one internal or external to it. The data stored is a blockchain decentralized ledger is a transaction type of database and others are not able to access it until the actual owner holds the private keys. These database file systems are more secure, faster, and economical compared to centralized databases. The potential for the use of blockchain technology in hospitals has developed a new field of healthcare data management and utilizes data encryption logics and supports to reduce data duplication via off-chain cloud components with cryptographic algorithms to create user sharing. Various types of possible healthcare data management systems include Blockchain for Electronic Medical Record (EMR) Data Management, Blockchain and Healthcare Data Protection, Blockchain for Personal Health Record (PHR) Data Management, Blockchain for Point-of-Care Genomics, and Blockchain for EHR Data Management [46]. Table 4 lists some of published research work on use of blockchain in Healthcare Data Management.

Table 4: Related scholarly work in Blockchain in Healthcare Data Management

\begin{tabular}{|l|l|l|l|}
\hline $\begin{array}{l}\text { S. } \\
\text { No. }\end{array}$ & Area & Issues and Outcome & Reference \\
\hline 1 & $\begin{array}{l}\text { Blockchain for } \\
\text { healthcare data } \\
\text { management }\end{array}$ & $\begin{array}{l}\text { Opportunities, challenges, and future } \\
\text { recommendations }\end{array}$ & $\begin{array}{l}\text { Yaqoob, I., et al. } \\
\text { (2021). [47] }\end{array}$ \\
\hline 2 & $\begin{array}{l}\text { IoT-healthcare using } \\
\text { blockchain technology }\end{array}$ & $\begin{array}{l}\text { A hybrid framework for multimedia } \\
\text { data processing }\end{array}$ & $\begin{array}{l}\text { Rathee, G., et al. } \\
\text { (2020). [48] }\end{array}$ \\
\hline 3 & $\begin{array}{l}\text { Blockchain for } \\
\text { healthcare data } \\
\text { management }\end{array}$ & $\begin{array}{l}\text { Blockchain versus database: a critical } \\
\text { analysis }\end{array}$ & $\begin{array}{l}\text { Chowdhury, M. J. M., } \\
\text { et al. (2018). [49] }\end{array}$ \\
\hline 4 & $\begin{array}{l}\text { Healthcare Data } \\
\text { Management Using } \\
\text { Blockchain Technology }\end{array}$ & Challenges and Future Work Directions & $\begin{array}{l}\text { Pustokhin, D. A., et } \\
\text { al. (2021). [50] }\end{array}$ \\
\hline 5 & $\begin{array}{l}\text { Blockchain for } \\
\text { healthcare data } \\
\text { management }\end{array}$ & $\begin{array}{l}\text { Blockchain technology acceptance in } \\
\text { electronic medical record system }\end{array}$ & $\begin{array}{l}\text { Wanitcharakkhakul, } \\
\text { L., et al. (2018). [51] }\end{array}$ \\
\hline
\end{tabular}

\subsection{Blockchain in strengthening Public Health Surveillance:}

Blockchain technology provides an opportunity to revamp the healthcare system improves the quality of its services through health-related data sharing between many players including patients, doctors, hospitals, and governance by ensuring selective privacy and data safety. It also provides a way to promote authentic patient centred data sharing with other stakeholders for remote management and monitoring of general health levels 
of the citizens of the countries. Furthermore, blockchain technology has the potential ability to strengthen disease surveillance systems in a country for possible chances of disease outbreaks resulting in local and global health emergencies. Such a real-time surveillance system based on blockchain technology with enhanced scalability, security, interoperability, and authenticity makes it optimum system for public health surveillance. The characteristics of blockchain system have capabilities of enhancing global health security and networking and hence ensures the anonymity of health data of individual patient thereby aiding healthcare research [52].

It is found that in blockchain based decentralized healthcare data records network, all modifications in the data and its transactions are recorded with real time updates in each node of the network. This stabilizes the data records in such a way that the stored information becomes permanent and can not be deleted or modified in a particular node without the knowledge other nodes. Thus, blockchain technology used in healthcare surveillance provides transparency, and autonomy to the network system and makes it a potential technology to improve the quality of healthcare service for the purpose of sharing the related data among all the stakeholders by improving interoperability, immutability, tighter security, reduced costs, and faster care delivery of healthcare records. Blockchain based surveillance system provides optimum characteristics such as systematic, ongoing collection, collation, and analysis of data and the timely dissemination of information to those who need to know so that the action can be taken. It enhances the quality of public surveillance for both infectious diseases and chronic noncommunicable diseases of national health systems, for effective disease surveillance, infectious disease control, and preventing the spread of epidemics [53]. Table 5 lists some of the related scholarly research in the application of Blockchain in Public Health Surveillance.

Table 5 : Related scholarly work in Blockchain in Public Health Surveillance

\begin{tabular}{|l|l|l|l|}
\hline $\begin{array}{l}\text { S. } \\
\text { No. }\end{array}$ & Area & Issues and Outcome & Reference \\
\hline 1 & $\begin{array}{l}\text { Use of Blockchain } \\
\text { technology in } \\
\text { healthcare }\end{array}$ & $\begin{array}{l}\text { In routine disease surveillance systems } \\
\text { to strengthen global health security }\end{array}$ & $\begin{array}{l}\text { Chattu, V. K., et al. } \\
\text { (2019). [53] }\end{array}$ \\
\hline 2 & $\begin{array}{l}\text { Blockchain based } \\
\text { healthcare platform }\end{array}$ & $\begin{array}{l}\text { pubHeal-A Decentralized Platform on } \\
\text { Health Surveillance of People }\end{array}$ & $\begin{array}{l}\text { Sharma, S. (2019). } \\
\text { [54] }\end{array}$ \\
\hline 3 & $\begin{array}{l}\text { Blockchain in } \\
\text { healthcare }\end{array}$ & Optimizing Disease Surveillance & $\begin{array}{l}\text { Coelho, F. C. (2018). } \\
\text { [55] }\end{array}$ \\
\hline 4 & $\begin{array}{l}\text { Blockchain in } \\
\text { healthcare }\end{array}$ & $\begin{array}{l}\text { Public health surveillance using } \\
\text { decentralized technologies }\end{array}$ & $\begin{array}{l}\text { Cisneros, J. L. B., et } \\
\text { al. (2018). [56] }\end{array}$ \\
\hline
\end{tabular}

\subsection{Blockchain in e-Healthcare to Customers:}

The current electronic medical record systems are customized to be used by a particular hospital only. In most cases, electronic medical records cannot be connected other hospitals and hence other hospitals cannot access patients' medical profile and hence patients receive minimum benefit when they try to receive medical facilities from other hospitals. Further, due to inferiority in the software used, the hospitals also cannot support more to provide e-healthcare facilities from other hospitals and the patients are not confident about the security and privacy of their data. Such problems are derived from three key issues that include completeness of data, sources and status of information, and data security in sharing [51]. Hence the e-healthcare system need patients records with correctness and completeness of the data. Blockchain in e-healthcare systems do not require multiple levels of authentication and provide access to data to everyone who is part of the blockchain architecture. In this system, the data is made visible and transparent for all stakeholders including patients, so that these features can be used to solve the various challenges faced by the healthcare industry for interoperability in a networked environment (Table 6).

Table 6 : Related scholarly work in Blockchain in e-Healthcare

\begin{tabular}{|l|l|l|l|}
\hline $\begin{array}{l}\text { S. } \\
\text { No. }\end{array}$ & Area & Issues and Outcome & Reference \\
\hline 1 & $\begin{array}{l}\text { Blockchain in e- } \\
\text { healthcare }\end{array}$ & $\begin{array}{l}\text { Use of blockchain in electronic } \\
\text { healthcare systems }\end{array}$ & $\begin{array}{l}\text { Alla, S., et al. (2018). } \\
{[57]}\end{array}$ \\
\hline
\end{tabular}




\begin{tabular}{|l|l|l|l|}
\hline 2 & $\begin{array}{l}\text { Blockchain in e- } \\
\text { healthcare }\end{array}$ & $\begin{array}{l}\text { Research Opportunities for E-health } \\
\text { Applications with DNA Sequence Data }\end{array}$ & $\begin{array}{l}\text { Neto, M. M., et al. } \\
\text { (2020). [58] }\end{array}$ \\
\hline 3 & $\begin{array}{l}\text { e-healthcare systems } \\
\text { with blockchain }\end{array}$ & $\begin{array}{l}\text { Investigating the progress of human e- } \\
\text { healthcare systems }\end{array}$ & $\begin{array}{l}\text { Jeet, R., et al. (2020). } \\
\text { [59] }\end{array}$ \\
\hline 4 & $\begin{array}{l}\text { Blockchain for public } \\
\text { health care }\end{array}$ & For developing in smart society & $\begin{array}{l}\text { Gul, M. J., et al } \\
\text { (2021). [60] }\end{array}$ \\
\hline 5 & $\begin{array}{l}\text { Blockchain technology } \\
\text { in e-healthcare } \\
\text { applications }\end{array}$ & $\begin{array}{l}\text { Access control and classifier-in } \\
\text { healthcare sector }\end{array}$ & $\begin{array}{l}\text { Maseleno, A., et al. } \\
\text { (2020). [61] }\end{array}$ \\
\hline 6 & $\begin{array}{l}\text { Blockchain-based } \\
\text { Smart Healthcare }\end{array}$ & $\begin{array}{l}\text { A Framework for Blockchain-based } \\
\text { Smart Health System }\end{array}$ & $\begin{array}{l}\text { Khubrani, M. M. } \\
\text { (2021). [62] }\end{array}$ \\
\hline 7 & $\begin{array}{l}\text { Blockchain-based e- } \\
\text { Healthcare }\end{array}$ & $\begin{array}{l}\text { An Improvised Model for Securing } \\
\text { Cloud-Based E-Healthcare Systems }\end{array}$ & $\begin{array}{l}\text { Kohli, R., et al. } \\
\text { (2021). [63] }\end{array}$ \\
\hline 8 & $\begin{array}{l}\text { Blockchain-based e- } \\
\text { Healthcare }\end{array}$ & $\begin{array}{l}\text { Security and Privacy in Cloud-Based E- } \\
\text { Health System }\end{array}$ & $\begin{array}{l}\text { Sivan, R., et al. } \\
\text { (2021). [64] }\end{array}$ \\
\hline
\end{tabular}

\subsection{Blockchain in Healthcare Administration \& Medicine Management:}

Based on its characteristics, blockchain can allow stakeholders in the healthcare ecosystem to share patient, treatment, and clinical information without compromising on security by ensuring information origin as well as change tracking. The blockchain based healthcare administration system gives patients a comprehensive, immutable log and easy access to their medical information across providers and treatment sites. Unique features of blockchain allows the administrators of healthcare systems to manage authentication, confidentiality, accountability and data sharing — crucial considerations when handling sensitive information. Integration of local data storage solutions to provide a modular design-based healthcare system. facilitates interoperability, system conveniency, and adaptability. Blockchain based Medicine Management system allows medical stakeholders such as researchers, public health authorities, etc. to participate in the network as administrators and researchers. Blockchain based integration of medical records provides ability to analyse information from various reliable sources to identify public health risks, develop new treatments and cures, and enable precision medicine [67]. Table 7 lists some of the related scholarly research on use of blockchain in Healthcare Administration \& Medicine Management.

Table 7 : Related scholarly work in Blockchain in Healthcare Administration \& Medicine Management

\begin{tabular}{|l|l|l|l|}
\hline $\begin{array}{l}\text { S. } \\
\text { No. }\end{array}$ & Area & Issues and Outcome & Reference \\
\hline 1 & $\begin{array}{l}\text { Blockchain in } \\
\text { Healthcare } \\
\text { Administration }\end{array}$ & $\begin{array}{l}\text { Artificial intelligence and blockchain } \\
\text { technology for transparency in } \\
\text { healthcare governance }\end{array}$ & $\begin{array}{l}\text { AlShamsi, M., et al. } \\
(2021) . \text { [65] }\end{array}$ \\
\hline 2 & $\begin{array}{l}\text { Blockchain in } \\
\text { Healthcare } \\
\text { Administration }\end{array}$ & $\begin{array}{l}\text { A Risk Analysis for Electronic Health } \\
\text { Records }\end{array}$ & $\begin{array}{l}\text { Ploder, C., et al. } \\
(2021) . \text { [66] }\end{array}$ \\
\hline 3 & $\begin{array}{l}\text { Blockchain Medicine } \\
\text { Management }\end{array}$ & $\begin{array}{l}\text { A framework for medical records } \\
\text { secure storage and secured medical } \\
\text { service }\end{array}$ & $\begin{array}{l}\text { Chen, Y., et al. } \\
(2019) . \text { [67] }\end{array}$ \\
\hline 4 & $\begin{array}{l}\text { Blockchain for digital } \\
\text { health }\end{array}$ & Prospects and challenges & $\begin{array}{l}\text { Evangelatos, N., et al. } \\
\text { (2020). [68] }\end{array}$ \\
\hline 5 & $\begin{array}{l}\text { Blockchain Medicine } \\
\text { Management }\end{array}$ & $\begin{array}{l}\text { Application of Blockchain and IoT in } \\
\text { Pharmaceutical services management }\end{array}$ & $\begin{array}{l}\text { Premkumar, A., et al. } \\
(2020) . \text { [69] }\end{array}$ \\
\hline
\end{tabular}

\subsection{Blockchain in Telehealth \& Telemedicine:}

Telehealth and telemedicine services can be improved and made more authentic using blockchain technology. Blockchain supports to make telehealth and telemedicine services to decentralize, fool-proof, trustful, transparent, traceable, reliable and secure by means of decentralized management approach. It helps the telehealth and telemedicine service to offer remote healthcare services to mitigate the spread of pandemic and chronical diseases systematically by means of optimum utilization of scarce resources in hospitals [70]. In 
this system, healthcare professionals are confidently able to monitor, diagnose, and treat patients belonging to remote places by offering cost-efficient services, thereby minimizing patient access and workforce limitations, expanding technology capabilities, and mitigating the risk of exposure of physicians, staff, or patients to pandemic diseases. The telehealth and telemedicine service uses Information Communication and Computation Technology (ICCT) to improve the quality of health services and to help the patients to manage their diseases through technology based access to awareness, education for precaution, and support systems. By using blockchain technology in existing telehealth and telemedicine systems, one can bring many authenticity based improvements including the successful establishment and the provenance of clinical data, legitimacy of users seeking patient data, manage identities of devices used for remote patient monitoring, preserve patient anonymity, and automate the payments settlement [70]. Table 8 lists some of the related scholarly work in Blockchain in Telehealth \& Telemedicine

Table 8 : Related scholarly work in Blockchain in Telehealth \& Telemedicine

\begin{tabular}{|l|l|l|l|}
\hline $\begin{array}{l}\text { S. } \\
\text { No. }\end{array}$ & Area & Issues and Outcome & Reference \\
\hline 1 & $\begin{array}{l}\text { Blockchain in } \\
\text { Telehealth }\end{array}$ & Blockchain-based healthcare system & $\begin{array}{l}\text { Hathaliya, J., et al. } \\
\text { (2019). [71] }\end{array}$ \\
\hline 2 & $\begin{array}{l}\text { Blockchain in } \\
\text { healthcare }\end{array}$ & $\begin{array}{l}\text { How this new technology benefits for } \\
\text { both patients and doctors focussed } \\
\text { applications }\end{array}$ & $\begin{array}{l}\text { Le Nguyen, T. (2018). } \\
\text { [72] }\end{array}$ \\
\hline 3 & $\begin{array}{l}\text { Blockchain in } \\
\text { telemedicine }\end{array}$ & $\begin{array}{l}\text { How Crypto-Economics is Redefining } \\
\text { Telemedicine }\end{array}$ & $\begin{array}{l}\text { Bennett, B. (2017). } \\
\text { [73] }\end{array}$ \\
\hline 4 & $\begin{array}{l}\text { Blockchain in } \\
\text { telehealth }\end{array}$ & $\begin{array}{l}\text { Using telehealth as a model for HIT } \\
\text { adoption }\end{array}$ & $\begin{array}{l}\text { Bennett, B. (2017). } \\
\text { [74] }\end{array}$ \\
\hline
\end{tabular}

\subsection{Blockchain in managing Medical Imaging:}

The unique advantage of blockchain technology is its ability to establish an anonymous record with a facility to authenticate to the participants whenever required. This feature allows blockchain technology to use as a tool to enable the patient-controlled, multi-organizational sharing of medical images without central authority permission in an interoperable health system [75]. Before the invention of blockchain based image storing and sharing, the digital imaging through high-speed network connectivity, the medical image sharing processes were using a copy in a physical storage medium such as CD or DVD and couriered between providers/users. This inefficient and waste inherent system can be solved by transcribing a digital asset onto optical media which commonly is read only once during image import at the receiving site. Further, this method imposes an undue responsibility upon the patient to ensure that the images are not lost, damaged, or intercepted in transit [76]. Many potential use cases for blockchain technology specifically relevant to medical imaging include image sharing of direct patient ownership of images, tracking of implanted medical devices, research, teleradiology, and artificial intelligence. Table 9 lists related scholarly work in Blockchain in managing Medical Imaging.

Table 9 : Related scholarly work in Blockchain in managing Medical Imaging

\begin{tabular}{|l|l|l|l|}
\hline $\begin{array}{l}\text { S. } \\
\text { No. }\end{array}$ & Area & Issues and Outcome & Reference \\
\hline 1 & $\begin{array}{l}\text { Blockchain in Medical } \\
\text { Imaging }\end{array}$ & $\begin{array}{l}\text { Blockchain based decentralized } \\
\text { autonomous imaging for data } \\
\text { processing }\end{array}$ & $\begin{array}{l}\text { Xu, R., et al. (2019). } \\
\text { [77] }\end{array}$ \\
\hline 2 & Blockchain in medicine & $\begin{array}{l}\text { Developing concept and } \\
\text { implementation of ultrasound medical } \\
\text { imaging systems for remote monitoring } \\
\text { of responses to neoadjuvant } \\
\text { chemotherapy in women's breast } \\
\text { cancer }\end{array}$ & $\begin{array}{l}\text { Shubbar, S. } \\
\text { (2017). [78] }\end{array}$ \\
\hline 3 & $\begin{array}{l}\text { Blockchain in Medical } \\
\text { Imaging }\end{array}$ & $\begin{array}{l}\text { Building a blockchain-based } \\
\text { decentralized storage system model }\end{array}$ & $\begin{array}{l}\text { Kumar, R., et al. } \\
\text { (2021). [79] }\end{array}$ \\
\hline
\end{tabular}




\begin{tabular}{|l|l|l|l|}
\hline 4 & $\begin{array}{l}\text { Leveraging Blockchain } \\
\text { for Medical Imaging } \\
\text { Research }\end{array}$ & $\begin{array}{l}\text { MarkIt- A Collaborative Artificial } \\
\text { Intelligence Annotation Platform }\end{array}$ & $\begin{array}{l}\text { Witowski, J., et al. } \\
(2021) . \text { [80] }\end{array}$ \\
\hline 5 & $\begin{array}{l}\text { Application of } \\
\text { Blockchain Technology } \\
\text { for Images }\end{array}$ & Imagechain & $\begin{array}{l}\text { Koptyra, K., et al. } \\
\text { (2021). [81] }\end{array}$ \\
\hline 6 & $\begin{array}{l}\text { Blockchain in Medical } \\
\text { Imaging }\end{array}$ & $\begin{array}{l}\text { An Integration of Blockchain and AI } \\
\text { for Secure Data Sharing and Detection } \\
\text { of CT images for the Hospitals }\end{array}$ & $\begin{array}{l}\text { Kumar, R., et al. } \\
\text { (2021). [82] }\end{array}$ \\
\hline 7 & $\begin{array}{l}\text { Secured Medical } \\
\text { Imaging using } \\
\text { blockchain }\end{array}$ & $\begin{array}{l}\text { Towards developing a secure medical } \\
\text { image sharing system based on zero } \\
\text { trust principles }\end{array}$ & $\begin{array}{l}\text { Sultana, M., et al. } \\
\text { (2021). [83] }\end{array}$ \\
\hline
\end{tabular}

\subsection{Blockchain in developing Smart Healthcare System:}

The combination of blockchain and smart healthcare can alleviate the pain points of traditional smart healthcare in information sharing, data security, and privacy maintenance, optimize the user-centered smart healthcare systems, and establish a multiparty medical alliance chain involving government, enterprises, and society. Such system demonstrates the usage of automated and intelligent blockchain for healthcare. Smart healthcare systems make use of Information Communication and Computation Technology (ICCT) underlying technologies such as Artificial Intelligence \& Machine learning, big data and business Intelligence, Cloud computing, Internet of Things, Wireless sensor networks, Mobile and wearable devices, Robotic surgeries, Information storage technology, Virtual reality, etc. Smart healthcare systems along with blockchain technology enhances confidentiality, integrity, authorization, and availability of data to the stakeholders in centralized, decentralized, and distributed environment (Table 10). The importance of creating secured electronic health records for easy sharing and access through ICCT underlying technologies and blockchain provides a secured yet faster way of medical information exchange in current scenario.

Table10 : Related scholarly work in Blockchain in developing Smart Healthcare System

\begin{tabular}{|c|c|c|c|}
\hline $\begin{array}{l}\text { S. } \\
\text { No. }\end{array}$ & Area & Issues and Outcome & Reference \\
\hline 1 & $\begin{array}{l}\text { Development of Smart } \\
\text { Health System }\end{array}$ & $\begin{array}{l}\text { A Framework for Blockchain-based } \\
\text { Smart Health System }\end{array}$ & $\begin{array}{l}\text { Mousa Mohammed } \\
\text { Khubrani, (2021). } \\
\text { [84] }\end{array}$ \\
\hline 2 & $\begin{array}{l}\text { Smart Health System } \\
\text { using Blockchain }\end{array}$ & $\begin{array}{l}\text { A Smart Healthcare Systems } \\
\text { Framework }\end{array}$ & $\begin{array}{l}\text { Demirkan, H. (2013). } \\
\text { [85] }\end{array}$ \\
\hline 3 & $\begin{array}{l}\text { Development of Smart } \\
\text { Health System }\end{array}$ & $\begin{array}{l}\text { Blockchain-powered smart healthcare } \\
\text { system }\end{array}$ & $\begin{array}{l}\text { Shukla, R. G., et al. } \\
(2020) .[86]\end{array}$ \\
\hline 4 & $\begin{array}{l}\text { Smart healthcare using } \\
\text { blockchain technology }\end{array}$ & $\begin{array}{l}\text { Towards secure and smart healthcare in } \\
\text { smart cities using blockchain }\end{array}$ & $\begin{array}{l}\text { Qiu, J., et al. (2018). } \\
\text { [87] }\end{array}$ \\
\hline 5 & $\begin{array}{l}\text { Blockchain and Smart } \\
\text { Contracts }\end{array}$ & $\begin{array}{l}\text { An Automated Approach towards } \\
\text { Smart Healthcare }\end{array}$ & $\begin{array}{l}\text { Haque, A. B., et al. } \\
(2021) .[88]\end{array}$ \\
\hline 6 & $\begin{array}{l}\text { Smart Healthcare } \\
\text { System and Blockchain } \\
\text { Network }\end{array}$ & $\begin{array}{l}\text { Platform for Integrating Internet of } \\
\text { Things }\end{array}$ & $\begin{array}{l}\text { Bhawiyuga, A., et al. } \\
\text { (2019). [89] }\end{array}$ \\
\hline 7 & $\begin{array}{l}\text { Healthcare } 4.0 \\
\text { Processes }\end{array}$ & $\begin{array}{l}\text { A Novel Smart Healthcare Design, } \\
\text { Simulation, and Implementation }\end{array}$ & $\begin{array}{l}\text { Kumar, A., et al. } \\
(2019) .[90]\end{array}$ \\
\hline 8 & $\begin{array}{l}\text { Secured Smart } \\
\text { Healthcare System }\end{array}$ & $\begin{array}{l}\text { Blockchain and Bayesian Inference } \\
\text { Based Approach }\end{array}$ & $\begin{array}{l}\text { Farhin, F., et al. } \\
(2021) .[91]\end{array}$ \\
\hline
\end{tabular}

\subsection{Blockchain in Healthcare Information System :}

Blockchain information system integrates various subsystems in hospital industry both horizontally and vertically so that it brings a reliable, and effective information management in healthcare organizations and the healthcare systems of the country. Here the blockchain technology could be used as a bridge that can 
provide information systems interoperability within a hospital or between different hospitals. Blockchain in healthcare information system allows to share records for information transactions. It enables all stakeholders in a team to securely share data with each other without a middleman and keep track of what was exchanged and when. Here the records are maintained across multiple computers, instead of being located on a single, hackable computer. This makes the information extremely difficult to tamper with or delete and hence provides the tamper-proof characteristic. Further, the process of information management ensures that any information added to the blockchain based healthcare system is valid, enables trust between the team members (Table 11).

Table 11 : Related scholarly work in Blockchain in Healthcare Information System

\begin{tabular}{|l|l|l|l|}
\hline $\begin{array}{l}\text { S. } \\
\text { No. }\end{array}$ & Area & Issues and Outcome & Reference \\
\hline 1 & $\begin{array}{l}\text { Blockchain Technology } \\
\text { in Healthcare } \\
\text { Information } \\
\text { Management Systems }\end{array}$ & $\begin{array}{l}\text { A Framework for the Adoption - A } \\
\text { Case Study of Nigeria }\end{array}$ & $\begin{array}{l}\text { Azogu, I., et al. } \\
\text { (2019). [92] }\end{array}$ \\
\hline 2 & $\begin{array}{l}\text { Blockchain technology } \\
\text { applications in global } \\
\text { health security }\end{array}$ & $\begin{array}{l}\text { The emerging role of in routine disease } \\
\text { surveillance systems to strengthen } \\
\text { global health security }\end{array}$ & $\begin{array}{l}\text { Chattu, V. K., et al. } \\
\text { (2019). [93] }\end{array}$ \\
\hline 3 & $\begin{array}{l}\text { Blockchain for } \\
\text { COVID-19 Health } \\
\text { Information system }\end{array}$ & $\begin{array}{l}\text { Blockchain for COVID-19: Review, } \\
\text { Opportunities, and a Trusted Tracking } \\
\text { System }\end{array}$ & $\begin{array}{l}\text { Marbouh, D., et. al. } \\
\text { (2020). [94] }\end{array}$ \\
\hline 4 & $\begin{array}{l}\text { Blockchain Technology } \\
\text { in Healthcare }\end{array}$ & $\begin{array}{l}\text { Moving Towards a Blockchain-Based } \\
\text { Healthcare Information System }\end{array}$ & $\begin{array}{l}\text { Balis, C., et al. (2019). } \\
\text { [95] }\end{array}$ \\
\hline
\end{tabular}

\section{DISADVANTAGES OF BLOCKCHAIN TECHNOLOGY :}

Some of the disadvantages of blockchain technology are listed below: [96-97]

(1) Blockchain technology involves completely new environment due to its complexity of use of cryptography as the working mechanism.

(2) Blockchains requires large network of users with a widely distributed grid of nodes and hence is difficult to get complete benefit of anti-fragility they respond to attacks and grow stronger.

(3) As network size of healthcare blockchain grows, transaction costs and network speed become challenges.

(4) Every Node in the blockchain runs in order to maintain consensus across its structure. This gives extreme levels of fault tolerance, ensures zero downtime, and makes data stored on the blockchain forever unchangeable and censorship-resistant. However, the computation speed becomes slower and more expensive than on a traditional system.

(5) To use a blockchain as a database in healthcare system, the information in it should be of high quality. This requires trustworthy, accurate, and high-quality data recording system.

(6) Continuous monitoring is required to avoid security flaw due to the probability of considering wrong information as right information.

(7) Since each participating node has to be verified during transaction and hence the total number of transactions occurring per second is limited. This leads to long transaction time and hence creates scalability issues.

(8) Blockchain suffers from the interoperability problem of functioning satisfactorily from different service providers and also to communicate seamlessly with each other. This challenge creates obstacles for effective data sharing.

(9) The information is vulnerable to possible protection and privacy threats even though not possible to modify.

(10) The blockchain is susceptible to attacks by selfish miners involved in collusion of the data.

\section{CURRENT IMPLEMENTATIONS OF BLOCKCHAIN IN HEALTHCARE :}

A blockchain is a chain of blocks apparently secured by cryptographic techniques [98-104]. His immutability is among the most desirable aspects of this to other businesses. No alteration can be made to the data added to the blockchain therefore, a consensus-based, verifiable and reliable database can be created. This makes 
blockchain especially ideal for tasks where data integrity is of utmost importance a practical illustration of this immutability is ProvChain, an infrastructure developed on the blockchain to provide data artifacts on the cloud with a chain of custody [105-107]. The advantages of blockchain are enormous in biomedical situations. Blockchain is suitable for implementations whereby biomedical / health care stakeholders independently regulated for example hospitals, manufacturers, patients, and contributors) choose to work together without giving power to a central management intermediary. Blockchain only allows functions that are very difficult to change data or registers to be developed and interpreted. As an unchangeable archive to store confidential information, blockchain is perfect for the example the history of insurance claims. Only under the cryptographic protocols can the owner change its ownership. The source of the assets can also be traced, which can be confirmed as sources or as data and documents, improving the reusability of the validated data, such as insurance transactions. Blockchain is, therefore, suitable for use in sensitive digital asset management for instance patient consent documents. The data redundancy can be accomplished by each node with a full copy of the historical data. Blockchain thus is perfect for maintaining and continued information availability for example EHR. The key advantage is to keep records secure with the use of cryptographic Algorithms [108]. In order to exchange and collaborate on personal health care data, a mobile, blockchain-based mechanism will be placed in place, a Hyperledger Fabric system will be introduced, which is a licensed blockchain requiring verifications of network nodes, and a privacy-providing personal health infrastructure with broader coverage of the health environment from the end-computer to cloud [109]. Blockchain can fit into interoperability as the right player by hashing the existing MPIs in the form of blocks to help reduce clinical costs, maintaining access to large population data in a decentralized format through which the gap between interoperability and predictability can be filled, and multi-source data from smart wearable devices to mobile devices can be achieved with blockchain because they can co-operate with blockchain [110-111].

\section{IDEAL CONDITION AND STATUS OF USING BLOCKCHAIN IN HEALTHCARE SECTOR :}

Blockchain consists of a growing list of records which are linked using cryptography and such chain has the property of transparency, decentralization, and immune to modifications. Ideal blockchain is capable to trace history of everything which created a footprint in the past. Blockchain consists of a growing list of records which are linked using cryptography and such chain has the property of transparency, decentralization, and immune to modifications.

Hence blockchain technology is optimum for medical record preservation for longer period especially for legal requirements in future days. Every aspect related to patient history, admission, treatment, discharge, and follow-up is recorded in non-destructive manner. Further any modification attempt is either not possible or will be known to everyone involved in the chain of activities. Though, achieving ideal status of nondestructiveness is impossible, the innovations and advents in blockchain technology has power to develop non-destructive chain of ledgers for secured documentation maintenance and cannot be modified individually at any point without the knowledge of others involved in it [112-114].

\section{RESEARCH GAP \& RESEARCH AGENDAS :}

Developing a method using Blockchain Technology to achieve 100\% security, transparency, decentralization, and immune to modifications compared to present status security, transparency, decentralization, and immunity for modifications. Challenge is how to improve these characteristics of healthcare services.

Further various research agendas in innovations in the healthcare sector using blockchain technology include: (1) Blockchain mediated Healthcare Security \& Authentication aspects of networked hospitals and patients,

(2) Blockchain application in Clinical Trials \& Precision Medicine to provide better information to stakeholders,

(3) Personalizing the Healthcare Services using Blockchain in terms of authenticity, completeness, and ubiquity,

(4) Healthcare Data Management assisted by Blockchain Technology as open access platform,

(5) The issues like (a) strengthening Public Health Surveillance using Blockchain Technology and provide current information to various monitoring bodies including government, (b) the use of blockchain technology to improve the quality of public surveillance systems at district level, country level, and global level and their integration with other technologies like geographical information system to expedite the routine epidemic investigations, drug and vaccine supply chain systems for efficient supplying on time,

(6) Blockchain assisted e-Healthcare to Customers with comparative service accessibility and quality,

(7) Optimum Healthcare Administration \& Medicine Management using Blockchain technology assisted 
security feature,

(8) Innovations and best practices in blockchain controlled Telehealth \& Telemedicine and to make it customer friendly,

(9) Managing and protecting of Medical Images using blockchain Technology,

(10) Developing Smart Healthcare Systems assisted by blockchain with user friendly and advanced comfort features, and

(11) Use of Blockchain for developing Innovative Healthcare Information Systems with automated and secured decision making processes.

\section{FINDINGS BASED ON THE REVIEW :}

(1) Blockchain technology has potential advantage in improving the healthcare services in the areas of Healthcare Security \& Authentication aspects, Clinical Trials \& Precision Medicine, Personalizing the Healthcare Services, Healthcare Data Management, Strengthening Public Health Surveillance, eHealthcare to Customers, Healthcare Administration \& Medicine Management, Telehealth \& Telemedicine, Managing Medical Imaging, Developing Smart Healthcare System, and Healthcare Information System.

(2) Adoption of blockchain in healthcare helps in establishing medical records which reduces the costs and also proper health data utilization.

(3) Blockchain can help healthcare in maintaining health records, drug data, patient data and insurance information.

(4) Transparency has the main function of blockchain helps to keep the information between medical facilities, insurance providers, and patients transparent.

(5) There are no universal health records for health data appropriate medical data management but blockchain has the potential to solve this problem.

(6) Understood about Blockchain technology and Distributed technology and how these technologies are changing the healthcare and financial services work.

(7) Interoperability being a major problem in healthcare blockchain can providing permission to digital access for clinical data, data availability, rapid access to clinical information, and patient identity and solve the problem.

(8) Blockchain improves contractual performance due to smart contracts

(9) Blockchain is mainly looked forward to the reason that it provides security

(10) When it comes to both healthcare and financial services blockchain promises security, transparency, trust, programmability, privacy, high performance, and scalability.

(11) Due to the programmable capabilities of blockchain, the code that addresses KYC can be built into assets themselves.

(12) Blockchain has become a disruptive technology with being used for different purposes from cost reduction to security in healthcare and financial services.

(13) The interest in testing and using the technology has drastically grown.

(14) Interoperability problem arises in blockchain because most of the blockchain work in silos and do not communicate with other peer networks as they are incapable of sending and receiving information from another blockchain based systems.

(15) The technology works on proof of work which needs a lot of computational power to solve complex mathematical puzzles, verify, and to secure the entire network.

(16) Identified various research agendas to carry out further research for patient satisfaction and comfortability.

\section{CONCLUSION :}

This study analyzed the emerging blockchain technology and its potential ramifications in healthcare and financial services. The blockchain technology provides a decentralized network and is considered to have tremendous potential for use in healthcare and financial services, due to the sensitive nature of the collection and management of data. The review aimed at defining the existing state of blockchain in healthcare and financial services and the current implementations in these industries. To achieve this aim, we have taken into account numerous scholarly publications concerning healthcare and financial services and challenges. Our findings indicate that blockchain technology has tremendously changed the healthcare sector and financial sector in the area of storage of data, processing of data, transaction, security, and so on based on its 
current implementation stage. Therefore, Blockchain technology help replaces paper-based and manual transaction processing in financial services and healthcare provides new models for electronic medical records and financial payments. It is found that blockchain technology facilitates for the improvement of quality services in the healthcare sector and various research agendas are proposed to carry out further research for patient satisfaction and comfortability.

\section{REFERENCES :}

[1] Aithal, P. S., \& Aithal, S. (2019). Management of ICCT underlying Technologies used for Digital Service Innovation. International Journal of Management, Technology, and Social Sciences (IJMTS), 4(2), 110136.

[2] Lipsey, Richard; Kenneth I. Carlaw; Clifford T. Bekhar (2005). Economic Transformations: General Purpose Technologies and Long-Term Economic Growth. Oxford University Press. pp. 131-218. ISBN 0-19-928564-0.

[3] Aithal, P. S., \& Aithal, S. (2018). Study of various General-Purpose Technologies and Their Comparison towards developing Sustainable Society. International Journal of Management, Technology, and Social Sciences (IJMTS), (2018), 3(2), 16-33.

[4] Aithal, P. S. \& Madhushree, L. M. (2019). Information Communication \& Computation Technology (ICCT) as a Strategic Tool for Industry Sectors. International Journal of Applied Engineering and Management Letters (IJAEML), 3(2), 65-80.

[5] Aithal, P. S. \& Madhushree L. M. (2019). Emerging Trends in ICCT as Universal Technology for Strategic Development of Industry Sectors. Chapter in a Book - IT and Computing for all the Domains and Professionals: The Emergence of Computer and Information Sciences, Edited by P.K. Paul, A. Bhuimali, K.S. Tiwary, and P. S. Aithal published by New Delhi Publishers, New Delhi. pp 1-26, ISBN: 978-93-88879-66-8.

[6] Aithal, P. S. \& Shubhrajyotsna Aithal (2019). Management of ICCT underlying Technologies used for Digital Service Innovation. International Journal of Management, Technology, and Social Sciences (IJMTS), 4(2), 110-136.

[7] Luu, L., Teutsch, J., Kulkarni., \& Saxena, P. (2015). Demystifying incentives in the consensus computer. Proceedings of the 22nd ACM SIGSAC Conference on Computer and Communications Security, 1(1), 706-719.

[8] Wright, A., \& De Filippi, P. (2015). Decentralized blockchain technology and the rise of lexcryptographia. Available at SSRN 2580664.

[9] Yaga, D., Mell, P., Roby, N., \& Scarfone, K. (2019). Blockchain technology overview. arXiv preprint arXiv:1906.11078.

[10] Peters, G., Panayi, E., \& Chapelle, A. (2015). Trends in cryptocurrencies and blockchain technologies: A monetary theory and regulation perspective. Journal of Financial Perspectives, 3(3), 1-46.

[11] Foroglou, G., \& Tsilidou, A. L. (2015). Further applications of the blockchain. Abgerufen Am. 3(1), 19.

[12] Gordon, W. J., \& Catalini, C. (2018). Blockchain technology for healthcare: facilitating the transition to patient-driven interoperability. Computational and structural biotechnology journal, 16(1), 224-230.

[13] Reyes, C. L. (2016). Moving beyond Bitcoin to an endogenous theory of decentralized ledger technology regulation: An initial proposal. Vill. L. Rev., 61(1), 191-204.

[14] Tripathi, G., Ahad, M. A., \& Paiva, S. (2020, March). S2HS-A blockchain based approach for smart healthcare system. Healthcare, 8(100391), 1-13.

[15] Honar Pajooh, H., Rashid, M., Alam, F., \& Demidenko, S. (2021). Multi-layer blockchain-based security architecture for internet of things. Sensors, 21(3), 1-26.

[16] Pandey, P., \& Litoriya, R. (2020). Securing and authenticating healthcare records through blockchain 
technology. Cryptologia, 44(4), 341-356.

[17] Srivastava, G., Parizi, R. M., \& Dehghantanha, A. (2020). The future of blockchain technology in healthcare internet of things security. Blockchain Cybersecurity, Trust and Privacy, 161-184.

[18] Soni, S., \& Bhushan, B. (2019, July). A comprehensive survey on blockchain: Working, security analysis, privacy threats and potential applications. In 2019 2nd International Conference on Intelligent Computing, Instrumentation and Control Technologies (ICICICT) (Vol. 1, pp. 922-926). IEEE.

[19] Kumar, N. M., \& Mallick, P. K. (2018). Blockchain technology for security issues and challenges in IoT. Procedia Computer Science, 132, 1815-1823.

[20] Neto, M. M., Coutinho, E. F., Moreira, L. O., \& de Souza, J. N. (2019, October). Toward blockchain technology in IoT applications: an analysis for e-health applications. In IFIP International Internet of Things Conference (pp. 36-50). Springer, Cham.

[21] Vora, J., Nayyar, A., Tanwar, S., Tyagi, S., Kumar, N., Obaidat, M. S., \& Rodrigues, J. J. (2018, December). BHEEM: A blockchain-based framework for securing electronic health records. In 2018 IEEE Globecom Workshops (GC Wkshps) (pp. 1-6). IEEE.

[22] Carlisle B, Kimmelman J, Ramsay T, MacKinnon NJCT. (2015). Unsuccessful trial accrual and human subjects' protections: an empirical analysis of recently closed trials. Clinical Trials, 12(1), 77-83.

[23] Szabo, N. (1996). Smart Contracts: Building Blocks for Digital Markets. Extropy. The Journal of Transhumanist Thought, 16(18), 2-20.

[24] Christidis, K., \& Devetsikiotis, M. (2016). Blockchains and smart contracts for the internet of things. Ieee Access, 4(1), 2292-2303.

[25] Buterin, V. (2014). A next-generation smart contract and decentralized application platform. white paper, 3(1), 1-36.

[26] Wong, D. R., Bhattacharya, S., \& Butte, A. J. (2019). Prototype of running clinical trials in an untrustworthy environment using blockchain. Nature communications, 10(1), 1-8.

[27] Nugent, T., Upton, D., \& Cimpoesu, M. (2016). Improving data transparency in clinical trials using blockchain smart contracts. F1000Research, 5 (2541). 1-7.

[28] Maslove, D. M., Klein, J., Brohman, K., \& Martin, P. (2018). Using blockchain technology to manage clinical trials data: a proof-of-concept study. JMIR medical informatics, 6(4), e11949, 1-7.

[29] Benchoufi, M., Porcher, R., \& Ravaud, P. (2017). Blockchain protocols in clinical trials: Transparency and traceability of consent. F1000Research, 6(1), 1-66.

[30] Benchoufi, M., \& Ravaud, P. (2017). Blockchain technology for improving clinical research quality. Trials, 18(1), 1-5.

[31] Angeletti, F., Chatzigiannakis, I., \& Vitaletti, A. (2017, September). The role of blockchain and IoT in recruiting participants for digital clinical trials. In 2017 25th International Conference on Software, Telecommunications and Computer Networks (SoftCOM) (pp. 1-5). IEEE.

[32] Borioli, G. S., \& Couturier, J. (2018). How blockchain technology can improve the outcomes of clinical trials. British Journal of Healthcare Management, 24(3), 156-162.

[33] Choudhury, O., Fairoza, N., Sylla, I., \& Das, A. (2019). A blockchain framework for managing and monitoring data in multi-site clinical trials. arXiv preprint arXiv:1902.03975., 1-13.

[34] Omar, I. A., Jayaraman, R., Salah, K., Simsekler, M. C. E., Yaqoob, I., \& Ellahham, S. (2020). Ensuring protocol compliance and data transparency in clinical trials using Blockchain smart contracts. $B M C$ Medical Research Methodology, 20(1), 1-17.

[35] Shae, Z., \& Tsai, J. J. (2017, June). On the design of a blockchain platform for clinical trial and precision medicine. In 2017 IEEE 37th international conference on distributed computing systems (ICDCS) (pp. 1972-1980). IEEE. 
[36] Zhuang, Y., Atkins, A., Shyu, C. R., Shae, Z., Tsai, J. J., \& Hsu, C. (2018). A Hybrid Blockchain Design for Patient Recruitments and Persistent Monitoring for Clinical Trials. IEEE Standards Association: Blockchain for clinical trials. 1-7.

[37] Jung, H. H., \& Pfister, F. M. (2020). Blockchain-enabled clinical study consent management. Technology Innovation Management Review, 10(2), 14-24.

[38] Leeming, G., Cunningham, J., \& Ainsworth, J. (2019). A ledger of me: personalizing healthcare using blockchain technology. Frontiers in medicine, 6(171), 1-10. 6(171), 1-10.

[39] Chenthara, S., Ahmed, K., Wang, H., \& Whittaker, F. (2020, October). A Novel Blockchain Based Smart Contract System for eReferral in Healthcare: HealthChain. International Conference on Health Information Science (pp. 91-102). Springer, Cham.

[40] Zhuang, Y., Sheets, L. R., Chen, Y. W., Shae, Z. Y., Tsai, J. J., \& Shyu, C. R. (2020). A patient-centric health information exchange framework using blockchain technology. IEEE journal of biomedical and health informatics, 24(8), 2169-2176.

[41] Lee, H. A., Kung, H. H., Udayasankaran, J. G., Kijsanayotin, B., Marcelo, A. B., Chao, L. R., \& Hsu, C. Y. (2020). An architecture and management platform for blockchain-based personal health record exchange: Development and usability study. Journal of Medical Internet Research, 22(6), e16748.

[42] Evangelatos, N., Özdemir, V., \& Brand, A. (2020). Blockchain for digital health: Prospects and challenges. Omics: a journal of integrative biology, 24(5), 237-240.

[43] El Rifai, O., Biotteau, M., de Boissezon, X., Megdiche, I., Ravat, F., \& Teste, O. (2020, September). Blockchain-Based Personal Health Records for Patients' Empowerment. In International Conference on Research Challenges in Information Science (pp. 455-471). Springer, Cham.

[44] StClair, J., Ingraham, A., King, D., Marchant, M. B., McCraw, F. C., Metcalf, D., \& Squeo, J. (2020). Blockchain, Interoperability, and Self-Sovereign Identity: Trust Me, It's My Data. Blockchain in Healthcare Today. 3(1), 1-3.

[45] Fiaidhi, J., Mohammed, S., \& Mohammed, S. (2018). EDI with blockchain as an enabler for extreme automation. IT Professional, 20(4), 66-72.

[46] Dimiter V. Dimitrov, (2019). Blockchain Applications for Healthcare Data Management. Healthcare Inform Res., 25(1), 51-56.

[47] Yaqoob, I., Salah, K., Jayaraman, R., \& Al-Hammadi, Y. (2021). Blockchain for healthcare data management: Opportunities, challenges, and future recommendations. Neural Computing and Applications, 1-16.

[48] Rathee, G., Sharma, A., Saini, H., Kumar, R., \& Iqbal, R. (2020). A hybrid framework for multimedia data processing in IoT-healthcare using blockchain technology. Multimedia Tools and Applications, 79(15), 9711-9733.

[49] Chowdhury, M. J. M., Colman, A., Kabir, M. A., Han, J., \& Sarda, P. (2018, August). Blockchain versus database: a critical analysis. In 2018 17th IEEE International Conference on Trust, Security and Privacy in Computing and Communications/12th IEEE International Conference on Big Data Science and Engineering (TrustCom/BigDataSE) (pp. 1348-1353). IEEE.

[50] Pustokhin, D. A., Pustokhina, I. V., \& Shankar, K. (2021). Challenges and Future Work Directions in Healthcare Data Management Using Blockchain Technology. In Applications of Blockchain in Healthcare (pp. 253-267). Springer, Singapore.

[51] Wanitcharakkhakul, L., \& Rotchanakitumnuai, S. (2017, December). Blockchain technology acceptance in electronic medical record system. In The 17th International Conference on Electronic Business, Dubai, UAE. 53-58.

[52] Bhattacharya, S., Singh, A., \& Hossain, M. M. (2019). Strengthening public health surveillance through blockchain technology. AIMS public health, 6(3), 326-333. 
[53] Chattu, V. K., Nanda, A., Chattu, S. K., Kadri, S. M., \& Knight, A. W. (2019). The emerging role of blockchain technology applications in routine disease surveillance systems to strengthen global health security. Big Data and Cognitive Computing, 3(25), 1-10.

[54] Sharma, S. (2019, December). pubHeal-A Decentralized Platform on Health Surveillance of People. In 2019 IEEE Pune Section International Conference (PuneCon) (pp. 1-6). IEEE.

[55] Coelho, F. C. (2018). Optimizing Disease Surveillance by Reporting on the Blockchain. bioRxiv, 278473.

[56] Cisneros, J. L. B., Aarestrup, F. M., \& Lund, O. (2018). Public health surveillance using decentralized technologies. Blockchain in Healthcare Today, 1(1), 1-14.

[57] Alla, S., Soltanisehat, L., Tatar, U., \& Keskin, O. (2018, May). Blockchain technology in electronic healthcare systems. In Proceedings of the 2018 IISE Annual Conference (pp. 1-6).

[58] Neto, M. M., Marinho, C. S. D. S., Coutinho, E. F., Moreira, L. O., Machado, J. D. C., \& de Souza, J. N. (2020, March). Research Opportunities for E-health Applications with DNA Sequence Data using Blockchain Technology. In 2020 IEEE International Conference on Software Architecture Companion (ICSA-C) (pp. 95-102). IEEE.

[59] Jeet, R., \& Kang, S. S. (2020). Investigating the progress of human e-healthcare systems with understanding the necessity of using emerging blockchain technology. Materials Today: Proceedings. DOI: https://doi.org/10.1016/j.matpr.2020.10.083.

[60] Gul, M. J., Subramanian, B., Paul, A., \& Kim, J. (2021). Blockchain for public health care in smart society. Microprocessors and Microsystems, 80(1), 103524, 1-8.

[61] Maseleno, A., Hashim, W., Perumal, E., Ilayaraja, M., \& Shankar, K. (2020). Access control and classifier-based blockchain technology in e-healthcare applications. In Intelligent Data Security Solutions for e-Health Applications (pp. 151-167). Academic Press.

[62] Khubrani, M. M. (2021). A Framework for Blockchain-based Smart Health System. Turkish Journal of Computer and Mathematics Education (TURCOMAT), 12(9), 2609-2614.

[63] Kohli, R., Garg, A., Phutela, S., Kumar, Y., \& Jain, S. (2021). An Improvised Model for Securing CloudBased E-Healthcare Systems. In IoT in Healthcare and Ambient Assisted Living (pp. 293-310). Springer, Singapore.

[64] Sivan, R., \& Zukarnain, Z. A. (2021). Security and Privacy in Cloud-Based E-Health System. Symmetry, 13(5), 742, 1-14.

[65] AlShamsi, M., Salloum, S. A., Alshurideh, M., \& Abdallah, S. (2021). Artificial intelligence and blockchain for transparency in governance. In Artificial Intelligence for Sustainable Development: Theory, Practice and Future Applications (pp. 219-230). Springer, Cham.

[66] Ploder, C., Spiess, T., Bernsteiner, R., Dilger, T., \& Weichelt, R. (2021). A Risk Analysis on Blockchain Technology Usage for Electronic Health Records. Cloud Computing and Data Science, 2(2), 1-16.

[67] Chen, Y., Ding, S., Xu, Z., Zheng, H., \& Yang, S. (2019). Blockchain-based medical records secure storage and medical service framework. Journal of medical systems, 43(1), 1-9.

[68] Evangelatos, N., Özdemir, V., \& Brand, A. (2020). Blockchain for digital health: Prospects and challenges. Omics: a journal of integrative biology, 24(5), 237-240.

[69] Premkumar, A., \& Srimathi, C. (2020, March). Application of Blockchain and IoT towards Pharmaceutical Industry. In 2020 6th International Conference on Advanced Computing and Communication Systems (ICACCS) (pp. 729-733). IEEE.

[70] Ahmad, R. W., Salah, K., Jayaraman, R., Yaqoob, I., Ellahham, S., \& Omar, M. (2021). The role of blockchain technology in telehealth and telemedicine. International Journal of Medical Informatics, 148(1), 104399, 1-11.

[71] Hathaliya, J., Sharma, P., Tanwar, S., \& Gupta, R. (2019, December). Blockchain-based remote patient 
monitoring in healthcare 4.0. In 2019 IEEE 9th International Conference on Advanced Computing (IACC) (pp. 87-91). IEEE.

[72] Le Nguyen, T. (2018, August). Blockchain in healthcare: A new technology benefit for both patients and doctors. In 2018 Portland International Conference on Management of Engineering and Technology (PICMET) (pp. 1-6). IEEE.

[73] Bennett, B. (2017). How Crypto-Economics is Redefining Telemedicine. Telehealth and Medicine Today, 2(6), 1-5.

[74] Bennett, B. (2017). Using telehealth as a model for blockchain HIT adoption. Telehealth and Medicine Today, 2(4), 1-4.

[75] Patel, V. (2019). A framework for secure and decentralized sharing of medical imaging data via blockchain consensus. Health informatics journal, 25(4), 1398-1411.

[76] McBee, M. P., \& Wilcox, C. (2020). Blockchain technology: principles and applications in medical imaging. Journal of digital imaging, 33(3), 726-734.

[77] Xu, R., Chen, S., Yang, L., Chen, Y., \& Chen, G. (2019, February). Decentralized autonomous imaging data processing using blockchain. In Multimodal Biomedical Imaging XIV (Vol. 10871, p. 108710U). International Society for Optics and Photonics.

[78] Shubbar, S. (2017). Ultrasound medical imaging systems using telemedicine and blockchain for remote monitoring of responses to neoadjuvant chemotherapy in women's breast cancer: concept and implementation (Doctoral dissertation, Kent State University).

[79] Kumar, R., \& Tripathi, R. (2021). Building an IPFS and Blockchain-Based Decentralized Storage Model for Medical Imaging. In Advancements in Security and Privacy Initiatives for Multimedia Images (pp. 19-40). IGI Global.

[80] Witowski, J., Choi, J., Jeon, S., Kim, D., Chung, J., Conklin, J., ... \& Do, S. (2021). MarkIt: A Collaborative Artificial Intelligence Annotation Platform Leveraging Blockchain for Medical Imaging Research. Blockchain in Healthcare Today, 4(176), 1-9.

[81] Koptyra, K., \& Ogiela, M. R. (2021). Imagechain-Application of Blockchain Technology for Images. Sensors, 21(1), 82.

[82] Kumar, R., Wang, W., Kumar, J., Yang, T., Khan, A., Ali, W., \& Ali, I. (2021). An Integration of Blockchain and AI for Secure Data Sharing and Detection of CT images for the Hospitals. Computerized Medical Imaging and Graphics, 87, 101812, 1-16.

[83] Sultana, M., Hossain, A., Laila, F., Taher, K. A., \& Islam, M. N. (2020). Towards developing a secure medical image sharing system based on zero trust principles and blockchain technology. BMC Medical Informatics and Decision Making, 20(1), 1-10.

[84] Mousa Mohammed Khubrani, (2021). A Framework for Blockchain-based Smart Health System. Turkish Journal of Computer and Mathematics Education, 12(9), 2609- 2614.

[85] Demirkan, H. (2013). A Smart Healthcare Systems Framework. IT Professional, 15(5), 38-45.

[86] Shukla, R. G., Agarwal, A., \& Shukla, S. (2020). Blockchain-powered smart healthcare system. In Handbook of Research on Blockchain Technology (pp. 245-270). Academic Press.

[87] Qiu, J., Liang, X., Shetty, S., \& Bowden, D. (2018, September). Towards secure and smart healthcare in smart cities using blockchain. In 2018 IEEE International Smart Cities Conference (ISC2) (pp. 1-4). IEEE.

[88] Haque, A. B., Muniat, A., Ullah, P. R., \& Mushsharat, S. (2021, February). An Automated Approach towards Smart Healthcare with Blockchain and Smart Contracts. In 2021 International Conference on Computing, Communication, and Intelligent Systems (ICCCIS) (pp. 250-255). IEEE.

[89] Bhawiyuga, A., Wardhana, A., Amron, K., \& Kirana, A. P. (2019, December). Platform for Integrating Internet of Things Based Smart Healthcare System and Blockchain Network. In 2019 6th NAFOSTED 
Conference on Information and Computer Science (NICS) (pp. 55-60). IEEE.

[90] Kumar, A., Krishnamurthi, R., Nayyar, A., Sharma, K., Grover, V., \& Hossain, E. (2020). A Novel Smart Healthcare Design, Simulation, and Implementation Using Healthcare 4.0 Processes. IEEE Access, 8(1), 118433-118471.

[91] Farhin, F., Kaiser, M. S., \& Mahmud, M. (2021). Secured Smart Healthcare System: Blockchain and Bayesian Inference Based Approach. In Proceedings of International Conference on Trends in Computational and Cognitive Engineering (pp. 455-465). Springer, Singapore.

[92] Azogu, I., Norta, A., Papper, I., Longo, J., \& Draheim, D. (2019, April). A Framework for the Adoption of Blockchain Technology in Healthcare Information Management Systems: A Case Study of Nigeria. In Proceedings of the 12th International Conference on Theory and Practice of Electronic Governance (pp. 310-316).

[93] Chattu, V. K., Nanda, A., Chattu, S. K., Kadri, S. M., \& Knight, A. W. (2019). The emerging role of blockchain technology applications in routine disease surveillance systems to strengthen global health security. Big Data and Cognitive Computing, 3(2), 25-38.

[94] Marbouh, D., Abbasi, T., Maasmi, F., Omar, I. A., Debe, M. S., Salah, K., ... \& Ellahham, S. (2020). Blockchain for COVID-19: Review, Opportunities, and a Trusted Tracking System. Arabian Journal for Science and Engineering, 45(1), 9895-9911.

[95] Balis, C., Tagopoulos, I., \& Dimola, K. (2019, July). Moving Towards a Blockchain-Based Healthcare Information System. In ICIMTH (pp. 168-171).

[96] Gatteschi, V., Lamberti, F., Demartini, C., Pranteda, C., \& Santamaria, V. (2018). To blockchain or not to blockchain: That is the question. IT Professional, 20(2), 62-74.

[97] Soltanisehat, L., Alizadeh, R., Hao, H., \& Choo, K. K. R. (2020). Technical, Temporal, and Spatial Research Challenges and Opportunities in Blockchain-Based Healthcare: A Systematic Literature Review. IEEE Transactions on Engineering Management, 1-16. DOI: 10.1109/TEM.2020.3013507.

[98] Bhuvana, R., Madhushree, L. M., \& Aithal, P. S. (2020). Blockchain as a Disruptive Technology in Healthcare and Financial Services-A Review based Analysis on Current Implementations. International Journal of Applied Engineering and Management Letters (IJAEML), 4(1), 142-155.

[99] Bhuvana, R., \& Aithal, P. S. (2020). Blockchain based Service: A Case Study on IBM Blockchain Services \& Hyperledger Fabric. International Journal of Case Studies in Business, IT, and Education (IJCSBE), 4(1), 94-102.

[100] Bhuvana, R., \& Aithal, P. S. (2020). RBI Distributed Ledger Technology and Blockchain-A Future of Decentralized India. International Journal of Management, Technology, and Social Sciences (IJMTS), 5(1), 227-237.

[101] Gade, Dipak S. \& Aithal, P. S. (2020). Blockchain Technology: A Driving Force in Smart Cities Development. International Journal of Applied Engineering and Management Letters (IJAEML), 4(2), 237-252.

[102] Rangi, P. K., \& Aithal, P. S. (2020). A Study on Blockchain Technology as a Dominant Feature to Mitigate Reputational Risk for Indian Academic Institutions and Universities. International Journal of Applied Engineering and Management Letters (IJAEML), 4(2), 275-284.

[103] Bhuvana, R., Madhushree, L., \& Aithal, P. S. (2020). Comparative Study on RFID based Tracking and Blockchain based Tracking of Material Transactions. International Journal of Applied Engineering and Management Letters (IJAEML), 4(2), 22-30.

[104] Sai Manoj K., \& P. S. Aithal, (2020). Blockchain Cyber Security Vulnerabilities and Potential Countermeasures. International Journal of Innovative Technology and Exploring Engineering (IJITEE), 9(5), 1516-1522.

[105] Kuo, T. T., \& Ohno-Machado, L. (2018). Model Chain: Decentralized privacy-preserving healthcare predictive 154 modelling framework on private blockchain networks. arXiv preprint arXiv:1802.01746. 
[106] McConaghy, T., Marques, R., Müller, A., De Jonghe, D., McConaghy, T., McMullen, G., ... \& Granzotto, A. (2016). Bigchaindb: a scalable blockchain database. white paper, BigChainDB, 1-70.

[107] Lorenz, J. T., Münstermann, B., Higginson, M., Olesen, P. B., Bohlken, N., \& Ricciardi, V. (2017). Blockchain in Insurance-Opportunity or Threat? McKinsey \& Company. http://www.mckinsey.com/ /media/McKinsey/Industries/Financial Services/Our Insights/Blockchain in insurance opportunity or threat/Blockchain-in-insurance-opportunity-or-threat.ashx. Accessed April 20, 2020.

[108] Liang, X., Zhao, J., Shetty, S., Liu, J., \& Li, D. (2017, October). Integrating blockchain for data sharing and collaboration in mobile healthcare applications. In 2017 IEEE 28th Annual International Symposium on Personal, Indoor, and Mobile Radio Communications (PIMRC) (pp. 1-5).

[109] Angraal, S., Krumholz, H. M., \& Schulz, W. L. (2017). Blockchain technology: applications in health care. Circulation: Cardiovascular Quality and Outcomes, 10(9), e003800.

[110] Rakic, D. (2018, March). Blockchain Technology in Healthcare. In ICT4AWE (pp. 13-20).

[111] William, J. (2016). Blockchain: The Simple Guide Everything You Need to Know. CreateSpace. Independent Publishing Platform.

[112] Aithal, P. S. (2019). Information Communication \& Computation Technology (ICCT) as a Strategic Tool for Industry Sectors. International Journal of Applied Engineering and Management Letters (IJAEML), 3(2), 65-80.

[113] Aithal, P. S., \& Aithal, S. (2019). Management of ICCT underlying Technologies used for Digital Service Innovation. International Journal of Management, Technology, and Social Sciences (IJMTS), 4(2), 110-136.

[114] Aithal, P. S., \& Aithal, S. (2019, October). Digital Service Innovation Using ICCT Underlying Technologies. In Proceedings of International Conference on Emerging Trends in Management, IT and Education (Vol. 1, No. 1, pp. 33-63). 